\title{
Bahamian Coloniality and Violence: Legal Legacies
}

\author{
Ian A. Bethell Bennett (Dhttps://orcid.org/0000-0002-8958-9581 \\ English Studies \\ University of The Bahamas \\ https://doi.org/10.15362/ijbs.v26i0.373
}

\begin{abstract}
The legacy of legal dispossession and dislocation as well as the marginalisation of the masses has been longstanding. This begins with land law that has never been updated to empower the people and moves through social or public order laws that are meant to protect the public by keeping order along the lines of Hobbesian and Lockeian thinking. If we look closely at a number of laws and political structures in the postcolony in the Anglophone Caribbean, we find that the legacy of Britain remains entrenched. This has both direct and indirect effects on the masses. The direct effect is Bahamians finding it harder to succeed in their own country than most international persons; and the indirect effect is violence and dispossession. This legacy and indirect effect lead to what has become referred to as a culture of violence, not because people see the violence they live with, but because they respond to the violence through violence they create and then become famous for. When a former subject, now a citizen in the postcolony, locked in a body and a space with few opportunities and access to those opportunities is frustrated by the legal and political economic systems, this working-class subject (like so many others) responds by resisting this oppression. Meanwhile, these laws continue to exact a heavy price.
\end{abstract}

\section{Introduction}

As Disney buys up over 1000 acres of a Bahamian island, and offers 120 local jobs, other sales are declared null and void in a court in the state of Florida where people have been buying and selling the same land many times over. Ports are cleaved off and effectively privatised while claiming they will bring in 100 jobs for Bahamians. Laws enable corporate exploitation and governmental monopolies. The language of social exclusion and legal separation through disempowerment has changed since the 19th century, but the effects have changed little since the move towards a more equitable representation in The Bahamas. Other Caribbean territories struggle with similar challenges.

An example of this legal violence is often seen as property deeds do not go with land, or even better stated: if you have a deed, someone may have a better deed than you. Such is the politics of land in the 21 st century Bahamas. The old laws such as the Quieting Titles Act (1959) can be used by those in power to disempower or dispossess those less fortunate. Those who have toiled in the post-emancipation, deeply segregated tourist economy of "A Nation for Sale" (Hiaasen \& McGee, 1984), watch as their human rights, birth right and access to the commons disappear, although they are often unaware of this erasure and dispossession. Globalisation has heralded the most interesting advancement of neoliberal and structural violence in some parts of the world since the initial encounter.

The masses, especially prior to the end of official segregation, lived in areas designed for them and were defined as violent. The laws that protected the safe, civilised space of settlement sought to ensure that no Blacks 
inhabited it. The native quarter (Fanon, 1961/1963), on the other hand, was exclusively for Blacks and was represented as a barbaric space of otherness, violence, and depravity.

Springer (2011) interestingly draws together spatial understandings of violence with the neoliberal approach to controlling violence with violence. This is undergirded by a historical colonial violence that assumes the other not to be human or deserving of human rights and the ability of the colonial power, through its implanting of English law, to dispossess and displace those who came to be in this place. In this instance, Springer's theorisation of violence sitting in spaces ties together well with Fanon's understanding that there are two spaces in the postcolonial world, and both spaces are imbued with meaning. In this case, the dichotomy between the two is what Springer explores as creating the Orientalist paradigm function. In this way, the paper explores how laws and (wedded with the) legal, political and economic system(s) are used to enforce a 21 st century postcolony, structural violence, where the reality that institutions do not allow some people to meet their basic needs is alive in the neoliberalism of international agencies assisting with development goals and strategies. In the Caribbean, then, much of the colonial structure continues to operate along the old, colonial paradigms of possession and dispossession. The conflation of common employment practices where many jobs are offered to foreign direct investors as a part of the deal and the local jobs are touted to be more than they are because lack of transparency can obfuscate any real information about employment, work permits and investment, many young nonwhite Bahamians find themselves struggling in a quagmire of structural violence, yet they have no name for it. As the national hospital allows people to wither and die quietly because they cannot afford private medical care, the structures of violence become more evident, but still often invisible. When this is conflated with the legal system that seeks to encourage development almost exclusively through foreign direct investment (FDI), the path becomes ever clearer.

Building on the Comaroffs' work (2006), this study is a cursory exploration of how colonial laws serve as blunt instruments to continue the oppression of formerly subject peoples. The work examines a few laws and how they continue to be used as tools to enact types of structural violence in what Comaroff and Comaroff refer to in Law and Disorder in the Postcolony. It is the use of law and disorder to approximate first world structures, and dispossess local groups, that is also always at play in the postcolony where most of the former subject people are displaced through laws and regulations that they are hardly aware of, or, if they are aware of them, they do not fully grasp how they are ultimately criminalised and disempowered or rendered voiceless through them. It is essential to underscore that there is no real difference between the imperial project and the colonial agenda, as Edward Said points out in Orientalism (1979) and later in Culture and Imperialism (1994). Laws work to ensure the success of the imperialist colonial project. Even when the colonial power has left, the system remains steadfastly entrenched.

This paradigm of dispossession through law and legal structures and systems started to dawn on me while teaching a course in American literature and the American dream; most students had no clue about the legality that oppressed them. In my tenure at the University of Puerto Rico, the student body was on the whole, incredibly engaged in their access to learning and their ability to learn. They did not take these things lightly because access had been such a hard fight for so many for so long. However, on coming to The Bahamas, it seemed that students were far less interested or even engaged in their education. Both these spaces were deeply colonised and indeed the coloniality of power continued to 
overshadow most things in The Bahamas which thought of itself as a completely postcolonial space. This is important because notwithstanding the push for independence in the 1950s-1970s, the space and structures therein remained and continue to remain influenced by coloniality. As MaldonadoTorres points out:

Coloniality is different from colonialism. Colonialism denotes a political and economic relation in which the sovereignty of a nation or a people rests on the power of another nation, which makes such nation an empire. Coloniality, instead, refers to longstanding patterns of power that emerged as a result of colonialism, but that define culture, labor, intersubjective relations, and knowledge production well beyond the strict limits of colonial administrations. Thus, coloniality survives colonialism. (2007, p. 243)

In many ways, the experience of teaching the American dream course was instructive for me as well as for the students as they learnt a great deal about Puerto Ricans' rights versus those of mainland Americans who could live in Puerto Rico and continue to exercise their original rights, whereas Puerto Ricans could not access those rights by virtue of the laws that represented them as other but seemingly liberated them. Further, they realised that their laws were and are secondary to United States laws. (This unequal relationship is cogently explored in work around the insular cases). Coloniality, then, provides a useful term for unpacking or unpicking the racialised, classist, gendered inequalities entrenched in laws which encourage and exploit spatial and economic differences. So, in The Bahamas, even though there is this intense pride around independence, coloniality maintains. The laws as much as custom retain their coloniality. Maldonado-Torres stresses that:

it is maintained alive in books, in the criteria for academic performance, in cultural patterns, in common sense, in the selfimage of peoples, in aspirations of self, and so many other aspects of our modern experience. In a way, as modern subjects we breath coloniality all the time. (2007, p. 243)

The power of law to define one's participation in one's home space and indeed one's ability to participate hinges on old supposedly outdated modes of control that would have been set asunder by post-colonial rule. In fact, however, these outdated modes of control remain steadfastly in place as coloniality. In Puerto Rico, to draw a parallel, the coloniality and in fact colonialism of the law remains clear, even though many younger people would not be cognisant of the fact, through the Foraker Act (1900) and the Jones-Safroth Act (1917). In The Bahamas, none of these obvious colonial laws operate. That does not mean that the laws, however much they appear to be postcolonial, remain in their effect colonial tools of oppression or tools of colonial oppression. This is the coloniality of law.

However, the laws that served to empower the Bay Street Boys and the Crown in The Bahamas served to disempower those who were silenced by those laws, namely the unrepresented majority, who, until 1962, did not enjoy voting rights, though the minority Bay Street Boys enjoyed the plural vote that the company Act gave them. Simultaneously, space/place, the settler community, with its paved roads and sidewalks, would be protected by the same law that served to keep the Blacks Over-the-Hill. The coloniality of power is seen in these laws that obviously controlled everything.

The Vagrancy Act (1939) speaks to the ways in which even in the supposed promised land of independence, many of the former subject peoples are rendered criminal in their land. This is perhaps a way of justifying the use of legal violence as a means to control illegality that is seen as inherent in the Black population. 
To be sure, the other had already been defined and socially excluded from the self. The self was white, civilised and European while the other was non-white, and uncivilised, what Springer notes above as the dichotomy between being civilised and the barbarism. Barbarism existed Over the Hill, according to law and othering. Springer argues thus:

Here again, violence sits in places; only in this case, through a grotesque representation of the 'Other', the virulent imaginative geographies of neoliberal discourse erase the contingency, fluidity, and interconnectedness of the spaces in which all violent narratives are formed. In other words, violence is problematically framed as though it is particular to a specific place/culture, rather than acknowledging the complex relational geographies that give rise to its formation and expression. (Springer, 2011, p. 95)

The historical and current obfuscation of this separation is essential to understand how the discourse continues to reproduce itself. So, while the post-emancipation Bahamas enjoyed the credit and truck system, little movement from poverty to wealth could occur for the majority as long as the system was in place. Up until 1962, this system continued to work, albeit in modified ways.

The othering inherent in the state's ability to disenfranchise and demonise a group of others is further explored in "Coloniality of Being and the Phenomenon of Violence" where NdlovuGatsheni and Chambati argue:

The notion of colonized peoples as barbarians and savages was popularized as colonizers sought various means to justify their domination, exploitation, repression and other abuses of Africans. MaldonadoTorres (2007, p. 245) argues that the ideology of barbarity of the colonized was sustained by 'a radical questioning or permanent suspicion regarding the humanity of the self in question'. He termed this imperial attitude, the 'racist/imperial Manichean misanthropic skepticism' that sustained the superiority of the imperial white being (MaldonadoTorres 2007, p. 245). It was used to justify the inferiority of the Black being under colonialism and is today hidden within structures of global coloniality where Westerners have remained at the top of racial hierarchies rooted in colonial modernity. (2013, p. 131)

So, as Bahamian lawmakers, politicians, and the oligarchy claim slavery ended, Blacks should be adjusted and get over it, and that slavery in The Bahamas was a 'gentler' form of slavery, the laws and politics remain steadfastly biased against most citizens. The imposed and structured inferiority of Blacks remained, though it has and is rarely mentioned, except to gain political expediency. This is yet another point that is rarely discussed in development paradigms: the legal disenfranchisement that has developed to incorporate subtler and more nuanced forms of exploitation and othering. The obvious bias against Blacks and in favour of international persons continues. As developmentally promotional laws such as the Hotels Encouragement Act (1954) draw international investors through lucrative tax breaks, the space must be safe for their enjoyment and the Penal Code (1924) and Vagrancy Act (1939) helps to ensure this spatial civility by legalising otherwise discriminatory policing practices.

The Vagrancy Act (1939) establishes that:

\section{VAGRANTS}

1. Being a person who, being able to work or by other lawful means to maintain himself or his family whom he or she may be legally bound to maintain, such person or family being without other means of support, refusing or neglecting so to do. 2 . Being a common prostitute, loitering or soliciting in a street or public place for the purpose of prostitution. 
3. Being a person wandering abroad or placing himself in any public place to beg or gather alms or cause or procure or encourage any child or young person, within the meaning of the Children and Young Persons Act, so to do.

4. Being a person who pretends or professes to tell fortunes.

5. Being a person who plays or bets (otherwise than in accordance with the provisions of any law for the time being in force permitting gaming) in any public place at any game or pretended game of chance or with any instrument of gaming (p. 4)

Despite the claim of Majority Rule and Independence, these laws have never been repealed; they remain constant reminders of ways to maintain law and order in the postcolony. This is one way of controlling or simply criminalizing postcolonial dependents. Given the breadth of scope of the Vagrancy Act (1939) and its continued life, this paper argues that the criminalising of bodies, especially in this case, Black male and in different ways female bodies, coincides with a bifurcation of power dynamics that allows bodies to be criminalised and the spatial control to be levied through the legal system to zone spaces within the postcolony.

So, while governments argue the need for FDI and that FDI cannot be taxed or that laws are only there to empower local development, the reality or result oppose this. On the face of these laws, the government argues, they are not biased or discriminatory; but their indirect effect is to create a dualistic reality/economy. Thus, those organisations that benefit under the Hotels Encouragement Act (1954), for example, will also benefit from acts brought to life by the (now) former Cabinet Minister and Minister for Immigration and Financial Services, who created the Commercial Enterprises Act (2017) that impugned the Immigration Department, a department he acknowledged was not working well, through legislating that if a response to a request for a work permit was not received within 14 days, the person would be allowed to work without said permit. The argument is that this makes life far more efficient and gives jobs to Bahamians. On the face of it, the Act does not do anything untoward; however, at its base it facilitates the freer movement of "qualified" people into the workforce, a complaint that companies that own hotels and resorts, along with other concerns like communications, electricity and water often have. (This thread is similarly explored in Puerto Rico, Cuba and Hawaii, as the insular cases allowed the U.S. Congress to bar many locals' access to investments, but facilitated United States natural and legal entities to preferential deals through amendments like the Platt Amendment (1901) and the Foraker Act (1900), among others, [Sparrow, 2006; Torruella, 2013]). These organisations generally argue that the local workforce, Blacks, are lazy and insufficiently educated and so they need to look abroad for good, qualified workers.

Notwithstanding the movement away from segregation and legalised discrimination, legacies of colonialism continue to perpetuate the violence of coloniality. As Comaroff and Comaroff argue:

Postcolonial societies, most of them rooted in historically extractive economies, with small bourgeois sectors, low levels of formal skill, and modest civil administrations, have shown varying capacities to profit from mainstream global enterprise. While a few have prospered, many fill a classic neocolonial niche: they are providers of raw materials and cheap labor. (2006, p. 10)

So, as The Bahamas is exploited for low-wage workers, but no longer really offers cheap labour, industries such as banks and insurance companies withdraw and re-establish themselves in former colonial spaces with 
cheaper labour markets. However, the acts that allow settler colonies to dispossess locals and empower settlers are not obviously or explicitly racist or openly discussed. They are subtly based on opening to international investors and allowing them benefits and privileges that locals are not afforded. Therefore, they cannot be called racist on their face, nor are they grouped together. The legislation is peppered with examples of these that either serve to promote international investors or work to delimit rights, abilities, benefits, and movement of local, workingclass Blacks. Again, comprehensive work on tourism policy and the insular cases across the American empire shows how legislation can operate to impose and uphold racially biased laws that disempower local populations.

While the laws seem unbiased on their face, the underlying motive across the multiple contexts is to control or suppress blackness and violently rid the colony of any vestiges of Africanness. These laws have varying impacts and go from controlling movement and access to controlling one's ability to practice Nonwestern religions. In Enacting Power: Criminalising Obeah in the Anglophone Caribbean (2013) Handler and Bilby explore exactly how anti-Obeah laws work to imprison and criminalize people in The Bahamas, for example, from evangelising or telling fortunes. The Vagrancy Act (1939) and the Penal Code (1924) hold various sections that continue to criminalise Obeah.

\section{Spatial Division}

There is also the spatial level captured so appropriately in Fanon's work that denotes and connotes spatial injustice through legal empowerment of one zone over the other as Fanon notes, "the colonial world is a world cut in two. The dividing line, the frontiers are shown by barracks and police stations. In the colonies it is the policeman and the soldier who are the official, instituted go-betweens, the spokesmen of the settler and his rule of oppression" (1961/1963, p. 38). This division is described even more blatantly:

The town belonging to the colonized people, or at least the native town, the Negro village, the medina, the reservation, is a place of ill fame, peopled by men of evil repute. They are born there, it matters little where or how; they die there, it matters not where, nor how. It is a world without spaciousness; men live there on top of each other, and their huts are built one on top of the other. The native town is a hungry town, starved of bread, of meat, of shoes, of coal, of light. The native town is a crouching village, a town on its knees, a town wallowing in the mire. It is a town of niggers and dirty Arabs. The look that the native turns on the settler's town is a look of lust, a look of envy; it expresses his dreams of possession--all manner of possession: to sit at the settler's table, to sleep in the settler's bed, with his wife if possible. The colonized man is an envious man. And this the settler knows very well; when their glances meet, he ascertains bitterly, always on the defensive, "They want to take our place." It is true, for there is no native who does not dream at least once a day of setting himself up in the settler's place. (1961/1963, p. 39)

This is the space inhabited by the criminalised body, where loose women and depraved men commingle, and criminal activity thrives. This has been the space of unplumbed homes without (indoor) running water or electricity so that in 2020 there are still people who are thrilled to find a flushing toilet, especially children when they go to school. Sadly, the schools in this area have tended to be less well maintained and funded. Education is also zoned.

Fanon's descriptor of the second or first space would now be termed the tourist zone.

The settlers' town is a strongly built town, all made of stone and steel. It is a brightly lit town; the streets are covered with 
asphalt, and the garbage cans swallow all the leavings, unseen, unknown and hardly thought about. The settler's feet are never visible, except perhaps in the sea; but there you're never close enough to see them. His feet are protected by strong shoes although the streets of his town are clean and even, with no holes or stones. The settler's town is a well-fed town, an easygoing town; its belly is always full of good things. The settlers' town is a town of white people, of foreigners. (1961/1963, p. 39)

This is the space of possibility, progress, and development. This is where the Hotels Encouragement Act (1954), the International Persons Landholding Act (1993), the Commercial Enterprises Act (2017), the Family Islands Development Encouragement Act (2008), the Industries Encouragement Act (1970), all work to encourage the space to shine and shimmer. None of these acts work in similar fashion in the so-called ghettos of New Providence. On Grand Bahama, the Hawksbill Creek, Grand Bahama (Deep Water Harbour and Industrial Area) Act (1955) that establishes Freeport is an act that is similar to this, except it delineates an entire swath of land, that has grown over the years and renewals, that is privately owned and an international Freeport.

Bahamians have an interesting relationship with Freeport. Teaching in The Bahamas for the last eight years has revealed that most young Bahamians in the educational system do not appreciate or understand the relationship between Freeport and The Bahamas or what Freeport is.

In its 2018 move to empower or Bahamians, the current Minnis administration argued that it would create a similar tax-free zone for Over-The-Hill communities that spanned the traditional Black communities of New Providence. Little work seems to have been done to challenge the current development and legal trends in The Bahamas by Bahamians that is disseminated in The Bahamas.

In this sponsorship programme, some of those entities enabled through legislation to avoid being tied to the local economy would donate to the plan. This reminds the reader that colonial enterprise, not dissimilar to imperialism, was very much alive.

Maldonado-Torres notes:

That is, some identities depict superiority over others. And such superiority is premised on the degree of humanity attributed to the identities in question. The 'lighter' one's skin is, the closer to full humanity one is, and viceversa. As the conquerors took on the role of mapping the world, they kept reproducing this vision of things. The whole world was practically seen in the lights of this logic. This is the beginning of 'global coloniality'. (2007, p. 244)

Meanwhile, this distinction is hardly challenged by the power system and so continues unabated. Members of Parliament and the clergy feel it within their rights to point out the obvious separation between settler communities and native quarters arguing that the native quarter needs to be more forcibly policed and that poor unwed mothers should have their tubes tied after two pregnancies.

Of course, this line of thinking normalises the othering of working-class Blacks and is buttressed by laws and socio-economic systems that seek to disempower much like they did during colonial times.

\section{Spatial Inequality, Inequity, and Injustice}

While we often discuss the power of Majority Rule, we often ignore the lagging results it has delivered for many Black working-class Bahamians since the 1980s. Much of the focus of successive governments has been on what Bahamians term the Stafford Sands model of development: Foreign Direct Investment or FDI. In earlier periods, that was controlled by 
acts such as the Immovable Property Act (1981) that was repealed by the 1992 Ingraham administration. The Act itself does not seek to harm, but the effects it has does impose a certain amount of harm. While arguing that it encourages development, the reality that it also skews the market and raises prices does not factor in. Further, as the benefits of most FDI is that they do not have to pay taxes or rather they have tax and import duty and other tax holidays, for example, they provide little to bolster true economic empowerment.

\section{Spatial Exclusion}

With the development of Albany, it was claimed that the answer to all Bahamians' problems was apparent. This is according to those who argue that employment is the panacea for all problems and heals all ills. However, these proponents of gated community development for international investors which equates to unequal/uneven development do not consider the spatial dynamics set in motion. Further, the laws that then buttress these offshore communities by allowing them to exist duty and tax free for the greatest part, act as a deterrent to local development. There are a number of studies that demonstrate the duality or uneven development created through a focus on FDI. However, because it is a short focus, the work will only show without going into detail how these dynamics arise and are empowered through the legislative framework.

\section{Historical Continuity}

Christopher Curry also creates a clear picture of the legal structure that allowed segregation based on race and colour. Curry begins an analysis of the laws and how they with intentional effect:

served to establish a method of controlling the free Blacks and enslaved population by ensuring they were listed and certified in a bound relationship either to a slave owner or to an employer ... the proclamation reinforced and codified the very power relations white Loyalists had begun to assert over Black Loyalists ... Black Loyalists were forced to agree to greater surveillance by both Justice of the Peace and employer. (Curry, 2017, p. 80)

Today, the discussion has returned to this, but the language is different. It is now coded in citizenship and citizen the protection of citizens from immigrants. Meanwhile, the continuity of legal policing to promote safe spaces and control riff-raff is clear, especially in the earlier period of the colony.

This has proven challenging today as similar trends continue to exist; though the anti-slave laws are long gone, the ways other laws have been allowed or encouraged to function results in similar kind of de facto criminalisation. All non-Bahamians, whomever they may be, and all Bahamians who may not "look" Bahamian are required to be in possession of a valid passport or government-issued identification or risk being rounded up, enmeshed in an immigration raid and deported to Haiti, where most of the "flood" is originating from. To my mind, then, policing continues to be around blackness, even though it has become coded in different language. While in the 19th century it was overtly used to control Black movement and thereby protect the white state, today it is used to control illegal Black movement and to protect the state.

This is seen/coded or read differently again when concerned with citizen protection and/or crime where, once again to turn to space or place, laws of private property are enforced in significant ways. The police are given carte blanche in Over-the-Hill communities, and also a different kind of power in resort areas. The laws speak very differently about how people are policed. This should mark a return to Springer's concept of violence sitting in places. So, to clarify, while the Over-the-Hill communities were established as spaces or places where Blacks were allowed to live by the laws of the time; restrictive covenants were 
formed in other areas designed for white settlers, including The Grove and Westward Villas, where Blacks and farm animals were not permitted. So, again, the violence sits in places where those who have been excluded by the law and then criminalised by the same law and the coloniality that would continue into the postcolonial state. The coloniality of the law is itself violence against the people, but the institutions create other forms of institutionalised violence that functions in the society. Policing is one of these and general care and treatment is another. So, while the African Hospital that once stood on Hospital Lane is no longer present, the coding of care remains in place through the public access to the public hospital that the Minister of Health himself has referred to as having an unofficial kind of apartheid. Those who can pay to access private care receive a totally different kind of attention than those who are on the public wards ("Treatment of Patients", 2019).

The separation or segregation that has been argued to have been removed in the 1950s and 1960s in politics by Dupuch (Craton \& Saunders, 1998/2000), is no less present in the gambling laws that prohibit Bahamians and residents from entering casinos. I would extend this here to argue that these casinos are what would have been called white owned and run and designed for tourist consumption so, once again for whites, in the past. Today, as indicated above, FDI remains the driver of tourism developed and it remains almost exclusively white, and this continues to be the space of casinos where Bahamians are still not allowed to gamble. They can, however, gamble in the number shops and casinos that have mushroomed Over-the-Hill since the opinion poll on gaming and a national lottery conducted under the second Christie government. The segregationist aspect of this distinction seems clear.

Springer (2011) and Soja (2010) seem to arrive at a similar place through different directions, arguing for what Fanon (1961/1963) would have seen as the violence that sits in the native quarter. As indicated above, this would have been an area legally set aside for negroes to settle and would have effectively been governed differently. Cleveland Eneas' (2007) and L. D. Powles' (1888/1996) works can be used to explore this. However, this paper wishes to draw on this to demonstrate, as Springer indicates that violence sits in places and these are the places that have been constructed as less than, inferior, ultimately criminal. Today, this is clearly borne out by the policing and violence in ghettoised areas. This marker has been changed or shifted to include the later developments set aside for lower or low-cost housing. Pinewood, Malcolm Allotment, Marshall Road, Elizabeth Estates are all areas that fit this description and experience greater levels of gang and interpersonal violence. So, while the laws treat these spaces violently and remove services from them or deliver lower quality services to them, as Fanon (1961/1963) argued, they in turn respond with violence. When the space is emptied of possibility, as Laurie Gunst (1995) explores in her work and so too does Deborah Thomas (2011), the youth usually respond by becoming what is expected of them.

At the same time, the laws that create inequalities are those that foster the delineation of space through FDI and tropicalisation. So, while Cable Beach and Paradise Island fit this model, Freeport and Albany fit a slightly different model and though they have no obvious racial segregationist policies, other than economics, they are clearly marked as off limits to most or beyond the aspirations of those students and young people who inhabit the other communities designed for them. While the government constantly makes the argument that FDI creates jobs and thereby fosters development; the stretch is far. The latter two examples pay nothing in real terms to the government to foster development. So, in using acts like The Hotels Encouragement Act (1954) and the Commercial Enterprises 
Act (2017) along with the Industries Encouragement Act (1970), entities can avoid paying anything close to what locals are required to pay. This kind of dual economy has been normalised and thereby the violence it inflicts has also been obfuscated and normalised. This is the coloniality of law.

\section{The Ecology of Internationalising the Economy: The Tripartite Approach}

While the governments of The Bahamas have been diligent in creating legislation that would attract international capital to the country, they have not done the same for local capital. The Ministry of Finance website gives information and contacts for each of the acts that promote FDI through economic benefits and tax exemptions. See, for example, the following laws:

The Hotels Encouragement Act - Provides duty free entry of approved construction materials, furnishings and fixtures for hotel development as well as provides for exemption/concession from real property tax for the first twenty years of operation of a hotel/resort.

Hotels with as few as four guest rooms on a Family Island and those with a minimum of ten rooms in New Providence qualify for concessions under the Hotels Encouragement Act.

The act has been amended to also include shops and restaurants, which have a touristic component, and entertainment facilities. (Bahamas Investment Authority, 2011, paras. 3-5)

The act attracts FDI by allowing them to have free access to the space and to invest capital in a way that facilitates fund transfers out of the local economy. This is further facilitated through the:

The Industries Encouragement Act Provides duty-free concessions for the importation of machinery, raw materials and building supplies for manufacturing entities in addition to exemption from Real Property Tax for a 15 -year period.

Duty free concessions for applicants is valid for the first five years of operation. Thereafter, applicants would be required to pay a reduced rate of duty (10\%) on all approved materials and equipment imported. (Bahamas Investment Authority, 2011, paras. 6-7)

The Family Island Development Encouragement Act - Provides duty concessions on the importation of building materials, equipment and supplies for commercial and/or residential developments on specified Family Islands. (Bahamas Investment Authority, 2011, para. 14)

Hawksbill Creek Agreement Act Allows the Port Area that is the free trade zone of Freeport, Grand Bahama, freedom from all taxes until 2015 and from excise taxes, stamp duties and most customs duties until 2054. (Bahamas Investment Authority, 2011, para. 10)

These laws work together to not only facilitate FDI but also to frustrate local investment through the lack of access to capital for local developers. On their face, none of these acts is discriminatory, but their operation results in the creation of a dual economy (Rodgers, 2010). The exemptions result in government not benefiting from the tax revenue these investments would bring, but rather their benefit would be limited to majority low-level employment.

In this instance, these acts work together with the newer Commercial Enterprises Act (2017) that facilitates the flow of investors into the country for $\$ 250,000$, which also allows them to access work permits. The laws facilitate a kind of flow that does not consider most of the local inhabitants who will not meet the basic requirements for most of these stipulations.

Consecutive governments claim they are aware 
of the inequalities Bahamians experience to access land and note that it produces uneven development as Tribune reporter Natario McKenzie notes: "K. Peter Turnquest, who was addressing The Bahamas Association of Land Surveyors' seminar, said the current system of land ownership and registration must change as it "retards" the ability of Bahamians to create wealth and realise economic opportunity" (2017). Nothing has been done to change this legal process. This points out how the law continues to disempower as access to land is an extremely important part of national development. This access tends to be classbased not simply due to the early land grants from the Lords Proprietors but also to the ways laws like the Quieting Titles Act (1959) allows more educated and powerful members of society to dispossess less well-off members by legally removing their access to what would have been their land through the legal acquisition of the land through establishing good deed in a Court of Law, what has been referred to as "land theft" (Hartnell, 2013; McKenzie, 2017).

McKenzie notes:

Developers and members of the real estate community have frequently urged the Government to reform the Quieting Titles Act to curb widespread land fraud/theft. The London-based Privy Council, this nation's highest court of appeal, has expressed concerns that The Bahamas' Quieting Titles Act can be used to steal land, saying it was "no accident" that it has heard numerous title disputes from this nation. (McKenzie, 2017)

This facilitation of international investment through exemptions also applies to government deals around crown land. Government's ability to give crown land to international developers has come under scrutiny because the premise of crown land is to encourage the development of Bahamians. However, as seen in recent developments on
Abaco, Mayaguana, and New Providence and Paradise Island, land goes to transnational companies (Dames, 2020). Simms (2019) explores some of the controversy around crown land, as does Hartnell (2020a, 2020b). It seems that crown land is overwhelmingly provided to FDI over Bahamians (Hartnell, 2013; Rolle, 2014). Meanwhile, government continues to hand over crown land as an investment incentive. The value of land ownership and the historical legacy behind early land grants are often eclipsed by political and legal obfuscation and by no Freedom of Information Act. While the ability to give land for FDI may be beneficial, the government's refusal to implement the already approved Freedom of Information Act allows the government to hide information from most citizens. Thus, secrecy behind Heads of Agreements, what they entail, and their actual signing is hidden. When the Free National Movement's Minnis administration came to office in 2017, its platform included assurances to implement the Freedom of Information Act.

This promise has not materialised. Instead, the government has taken advantage of its ability to encourage investors through secrecy as has been revealed with the Oban Energies oil lease and the separate Bahamas Petroleum Company, based in Isle of Man, and mostly functioning outside of The Bahamas sphere, but planning to drill in Bahamian waters. This just underscores the ability of legislation to hide facts and to create uneven development. The public's ability to access information is in part based on their ability to access education, another service that is unevenly distributed based on space, which is in turn based on class.

\section{Conflating Control with Possession and Knowledge}

If land ownership is a cornerstone to individual development and so national development, education is key to national development. Without an adequate education system, which should not be class-, spatially- or racially based, a nation fails to meet its potential. Many 
organisations studying the human capital reveal skills gaps. The Inter-American Development Bank, World Bank and United Nations have collected much data and presented reports on the need for soft skills, in particular (Hartnell, 2017).

Ultimately, education, as numerous studies have highlighted, directly and indirectly relates to national development and to criminality (Bethell-Bennett, 2014). One's ability to perform in society, to survive and to provide for oneself and family is also directly impacted by deep inequalities and laws carved out to police those inequalities. The ineffective education system and inadequate results encourages companies to import skilled labour, using the acts listed above, thus further entrenching the uneven development built through coloniality.

Meanwhile, the Vagrancy Act (1939), an extremely colonial law, imposes order by ensuring Blacks' movement is controlled and the ability to deprive them of their 'right' to congregate and to manifest against injustice without written permission. The act is much like the Sea Bathing Rules of 1939 (now repealed); however, the rules continue to signal colonial inequalities, maintains and encourages a gendered, racialised policing of space, as Fanon demonstrates, where Black males, in particular, are profiled (BethellBennett, 2014). The act establishes where and how one can gather while taken in tandem with the Lotteries and Gaming Act (1969), prior to the amendment of 2014 that legalised gambling for Bahamians, demonstrates colonial inspired unequal access to space.

Furthermore, the legalising of gaming for Blacks in particular establishments, not hotel casinos, is a clear indicator of economic and so, racialised inequality. Moreover, when the 2016 Gender Equality Referendum occurred, the constitution was set to be made more equitable for men and women. Though gender is not often seen as an indicator of structural and so systemic inequality in The Bahamas, its intersectionality with race and class, is that, again behind the Constitution that forbids women from transferring their citizenship to their foreign-born children if their father is not Bahamian, is a clear indicator of inequality. The state's ability to disempower women, who make up more than 50 percent of the population, speaks to a class and race-based uneven system. Women in elite groups would be more aware of their rights and ways to safeguard the same. They would also be more aware of ways of ensuring that even if they are married to non-Bahamians, they continue to enjoy citizenship rights and are more likely to pass on their citizenship to their children.

Working-class women, who would be less educated, would not be as aware of the structural encumbrances established against them passing on their citizenship and so they would be less likely to actively seek to change this and to demand citizenship. This inequality works to exclude poorer communities from citizenship and its rights, and further exacerbates the already existent inequality particularly between the poorer classes and those settlers and economic citizens who have more legal access through wealth and education.

This gender and racialised inequality, however, is a colonial staple that was not changed in The Bahamas until the Women's Suffrage Movement successful push for the right to vote in 1962. Of course, Bahamian governments, particularly the Colonial and then the United Bahamian Party's ability to silence and disempower all Blacks was clear until universal enfranchisement or suffrage was gained in 1958, for all men, but not women. Legislation was passed in the House of Assembly in 1961 allowing for universal adult suffrage in The Bahamas. All men were given the right vote in The Bahamas in 1958 . In 1807, legislation passed in the House of Assembly gave free persons of colour the right to vote; this overturned a pre-existent legal 
inequality that forbade Blacks to vote or from voting, even if they owned land, but it did continue the gendered, class-based, usually racial segregation between landholders and non-landholders (Craton \& Saunders, 1998/2000). Ultimately, even the supposed equalising effect of the Independence Orders of 1973 continued to enshrine deep inequalities.

Colonial settlers' fears of being overrun by Blacks and the spread of anti-slavery sentiment from the nearby French colony of SaintDomingue provoked an exclusionary practice that saw the exclusion of Blacks from entering The Bahamas, while Whites or the French could enter to escape persecution (Craton \& Saunders, 1998/2000). This anti-Haitian sentiment has continued and finds itself entrenched in many Bahamian attitudes to Haitians especially after Independence.

Perhaps the Immigration Act (2014) can also be used as a legal marker of racialised, classbased inequality because it targets poor migrant and immigrant communities in The Bahamas. It particularly or specifically targets Haitian and Bahamians born to two Haitians or one Haitian parent. These births would also be based around particular spaces. This spatial relationship between access to citizenship and education compared with other areas where access is all but guaranteed, speaks to deepening inequalities and uneven development. By making it more difficult for youngsters born in these areas to access education, the law creates deep and lasting inequalities that more middle class and elite parents and children do not experience. By insisting that children have proof of citizenship to access education, which most of this group is unable to provide at least until 18 , they are effectively barred from education even if it is a de facto discriminatory bar.

These laws, the economic development laws are undergirded by criminal laws and laws to promote order, and ultimately refashion the coloniality of development so that those inequalities established during colonisation not only continue, but in some areas deepen. This discrimination is not obvious or direct, but is mostly indirect, as is the case in Puerto Rico (Torruella, 2013).

\section{Shifting Lines/Changing Paradigms and Spaces}

While we understand the criminalisation of the Black body in particular contexts, and as Craton and Saunders (1998/2000) have illustrated Blacks were governed by laws that controlled where they went and how they occupied space, the ways in which The Vagrancy Act (1939) tacitly buttresses racist laws and protects public spaces from the plague of blackness, makes its use is less necessary when the space has already been effectively and legally sold off and gated. This is exemplified in Marina Village, a space created for tourists that has arguably helped to destroy Bay Street by establishing a privately owned and operated alternative space to the public thoroughfare. This is the preferred space too for young Black and White as well as Brown Bahamians to socialise on weekend evenings. As it is private, admission can be tightly controlled. This has been even more justified after violent fights broke out there in earlier times as young men brought their criminality with them to the space. This is the attitude of the law, not this paper. The policing and enforcing of a strict code of behaviour has been welcomed by the community, and the tourists are made to feel safer in the artificially created space. This is a phenomenon that has developed over time and has re-disguised the need for segregation in the language of protection and safety. So, as young people gather, they are closely surveilled. Because they are on private property, they have fewer rights to enjoy, though they are unaware of this. Further, as the entire island has been effectively privatised through the expansion of the resort which owns most of the coastal areas, the policing is as it is in any settler 
community as Fanon would argue, but it has also been put in private hands (1961/1963, p. 38). So, there is an effective neoliberalisation of the law and the use of fear and criminality to exclude many. The space has also created an economic barrier to access that frustrates many young people who see that they are unable to enjoy these spaces and who understand that they are treated badly when they do venture into these desired worlds. This is where the adage from Puerto Rican developer Jaime Gonzalez (2009) originates when he stated that such is life for those who cannot afford to buy or live in these spaces. The tropicalised beauty of this space eclipses the natural occurrence of beauty in the communities created for low cost housing: the areas where both Fanon and Springer (2011) argue, violence sits, not because it is indigenous to these spaces or places but because it has become endemic to them through the violent neoliberal coloniality of social exclusion through the law.

Many of these young people see these spaces as the only places they are able to escape the violence and fear of their communities where the drive by shooting can more than likely take their lives. Certainly, these thoughts are not espoused by public teenagers publically in these words, but they do articulate their evident or obvious social exclusion in other ways that are germane to them. It is not coincidental that the idea of colonial people as barbarians, as Maldonado-Torres (2007), Quijano (2000) and others have studied, is clearly at play in this regard. The space of otherness is defined as being occupied by Black males who are dangerous because they have been legally and socially excluded and disenfranchised. This has led to a level of disinfection and social death that creates even more violence. The Jaime Gonzalez's attitude is carried over in and by many developers who look at the law and disorder in the postcolony and see how they can benefit from it. At the same time, leaders have opted to allow this continued coloniality of space and being to pervade the country and to allow for deepening inequality and social death.

Ultimately, the conflation or confluence of neoliberalism and coloniality in The Bahamas means that laws such as the Hotels Encouragement Act (1954), the Family Islands Development Encouragement Act (2008), the Commercial Enterprises Act (2017), the Vagrancy Act (1939), The Lotteries and Gaming Act (1969), and the International Persons Landholding Act (1993) all work in concert to effectively dispossess the masses. In Springer's words:

By recognizing that the structural violence of neoliberalism is everywhere ... 'local' experiences of violence that seemingly occur in isolation from the wider matrix of space are in fact tied to the 'global', which renders violence somewhat 'everyday'. (Springer, 2011, p. 95)

Meanwhile, the violence argued as resident Over-the-Hill, that sits in a place is registered as a threat to national development and security and treated with harsh police brutality and legal impunity, but the structural and systemic violence of coloniality in the postcolony is normalised and invisibilised. 


\section{References}

Bahamas Investment Authority. (2011). Investment incentives [Webpage]. https://tinyurl.com/BahamasInvestmentAu thorityActs

Bethell Bennett, I. (2014). Fragile masculinities: The loss of young men and the pervasive models of masculinity in The Bahamas that encourage them to fail. Caribbean Review of Gender Studies, 8, 43-77.

https://sta.uwi.edu/crgs/december2014/jou rnals/CRGS_8_FragileMasculinities_Ben nett.pdf

Comaroff, J. L., \& Comaroff, J. (2006). Law and disorder in the postcolony: An introduction. In J. Comaroff \& J. L. Comaroff, Law and disorder in the postcolony (pp. 1-55). University of Chicago Press.

Craton, M., \& Saunders, G. (1998/2000). Islanders in the stream: A history of the Bahamian people: Vol. 2. From the ending of slavery to the twenty-first century. University of Georgia Press.

Curry, C. (2017). Freedom and resistance: A social history of Black loyalists in The Bahamas. University Press of Florida.

Dames, C. (2020, March 11). Bahamian project remains in limbo as crown land conflict unresolved. The Nassau Guardian. https://thenassauguardian.com /2020/03/11/bahamian-project-remains-inlimbo-as-crown-land-conflict-unresolved/

Eneas, C. W. (2007). Bain Town. (3rd ed.). Thought Katcher.

Fanon, F. (1963). The wretched of the earth (C. Farrington, Trans.). Grove Press. (Original work published 1961).
https://monoskop.org/images/6/6b/gonz_F rantz_The_Wretched_of_the_Earth_1963. pdf

Gonzalez, J. (2009). Porque de la abundancia del corazón habla la boca: Such is life. http://www.aprodec.net/orientepasugente/ Delaboca.html

Gunst, L. (1995). Born fi' dead: A journey through the Jamaican posse underworld. Henry Holt.

Handler, J. S., \& Bilby, K. M. (2013). Enacting power: Criminalising Obeah in the Anglophone Caribbean. University of the West Indies Press.

Hartnell, N. (2013, August 26). Government proposed 21-year lease of reclaimed crown land to Peter Nygard. The Tribune. http://www.tribune242.com /news/2013/aug/26/government-proposed21-year-lease-reclaimed-crown-/

Hartnell, N. (2017, January 5). IDB: Bahamas skills gaps are 'worrisome'. The Tribune. http://www.tribune242. com/news/2017/jan/05/idb-bahamasskills-gaps-are-worrisome/

Hartnell, N. (2020a, February 27). Royal Caribbean's PI land deals revealed. The Tribune. http://www.tribune242.com/ news/2020/feb/27/royal-caribbeans-piland-deals-revealed/

Hartnell, N. (2020b, March 22). Pushed into corner on Royal Caribbean deal. The Tribune. http://www.tribune242.com /news/2020/mar/02/pushed-corner-royalcaribbean-deal/

Hiaasen, C., \& McGee, J. (1984, September 23). A nation for sale: Corruption in The Bahamas. The Miami Herald. 
https://pdfslide.net/documents/a-nation-

for-sale-corruption-in-the-

bahamas.html?fbclid=IwAR2QuM5wZZb

o7_4cyTHnrRtc_By8NCaurkpBFL_D51d

pWPcky6YgXiVSVu8

Maldonado-Torres, N. (2007). On the coloniality of being. Cultural Studies: Globalization and the de-colonial option, 21(2-3), 240-270. https://doi.org/ $10.1080 / 09502380601162548$

McKenzie, N. (2017, November 3). DPM: Quieting Act 'inherently unfair'. The Tribune. http://www.tribune242.com /news/2017/nov/03/dpm-quieting-actinherently-unfair/

Ndlovu-Gatsheni, S. J, \& Chambati, W. (2013). Coloniality of being and the phenomenon of violence. In. S. J. NdlovuGatsheni, Coloniality of power in postcolonial Africa: Myths of decolonization (pp. 125-144). CODESRIA.

Powles, L. D. (1888/1996). The land of the pink pearl, or, recollections of life in The Bahamas. Media Enterprises

Quijano, A. (2000). The coloniality of power, Eurocentrism, and Latin America. Nepantla: Views from South, 1(3), 533 580. http://www.decolonialtranslation. com/english/quijano-coloniality-ofpower.pdf

Rodgers, K. J. (2010). Is it really better in The Bahamas for Bahamians? Media Enterprises.

Rolle, R. (2014, August 8). No response to 30,000 crown land applications. The Tribune. http://www.tribune242.com /news/2014/aug/08/no-response-30000crown-land-applications/
Said, E. (1979). Orientalism. Vintage.

Said, E. (1994). Culture and imperialism. Vintage.

Simms, R. A. (2019, June 17). Island insights: Crown land-ownership and management. The Tribune. http://www.tribune242.com/ news/2019/jun/17/island-insights-crownland-ownership-and-managemen/

Soja, E. (2010). Seeking spatial justice. University of Minnesota Press.

Sparrow, B. H. (2006). The insular cases and the emergence of an American empire. University of Kansas Press.

Springer, S. (2011). Violence sits in places? Cultural practice, neoliberal rationalism, and virulent imaginative geographies. Political Geography, 30, 90-98. https://doi.org/10.1016/j.polgeo.2011.01.0 04

Thomas, D. A. (2011). Exceptional violence: Embodied citizenship in transnational Jamaica. Duke University Press.

Torruella, J. R. (2013). Ruling America's colonies: The insular cases. Yale Law \& Policy Review, 32, 58-95. https://www.jstor.org/stable/23736226

Treatment of patients 'legalized apartheid' (2019, August 23). The Tribune. http://www.tribune242.com/news/2019/au g/23/treatment-of-patients-legalisedapartheid/ 


\section{Legislation}

Commercial Enterprises Act (2017) Bahamas

(No. 19 of 2017).

http://laws.bahamas.gov.bs/cms/images/LE

GISLATION/PRINCIPAL/2017/2017-

0019/CommercialEnterprisesAct2017_1.p

df

Family Islands Development Encouragement

Act (2008) Bahamas (Ch. 328A). http://laws.bahamas.gov.bs/cms/images/LE GISLATION/PRINCIPAL/2008/20080014/FamilyIslandsDevelopment

EncouragementAct_1.pdf

Freedom of Information Act (2017) Bahamas

(No. 1 of 1971).

https://www.bahamas.gov.bs/wps/wcm/co

nnect/f9b629d9-25a7-467a-971f-

d12b35082812/FreedomofInformationAct2

017_1.pdf?MOD=AJPERES

Hawksbill Creek, Grand Bahama (Deep

Water Harbour and Industrial Area) Act

(1955) Bahamas (Ch. 261).

http://laws.bahamas.gov.bs/cms/images/LE

GISLATION/PRINCIPAL/1955/1955-

0005/HawksbillCreekGrandBahama

DeepWaterHarbourandIndustrialAreaAct_ 1.pdf

Hotels Encouragement Act (1954) Bahamas

(Ch. 289). http://laws.bahamas.gov.bs/ cms/images/LEGISLATION/PRINCIPAL/ 1954/1954-

0030/HotelsEncouragementAct_1.pdf

Immovable Property (Acquisitons by Foreign

Persons) Act (1981) Bahamas (Ch. 125).

Industries Encouragement Act (1970)

Bahamas (Ch. 326). http://laws.bahamas

.gov.bs/cms/images/LEGISLATION/PRIN

CIPAL/1970/1970-0010/Industries

EncouragementAct_1.pdf
International Persons Landholding Act (1993)

Bahamas (Ch. 140).

http://laws.bahamas.gov.bs/cms/images/LE

GISLATION/PRINCIPAL/1993/

1993-0041/InternationalPersons

LandholdingAct_1.pdf

Lotteries and Gaming Act (1969) Bahamas

(Ch. 387). http://laws.bahamas.gov.bs/

cms/images/LEGISLATION/PRINCIPAL/

1969/1969-0008/

LotteriesandGamingAct_1.pdf

Penal Code (1924) Bahamas (Ch. 84). http://laws.bahamas.gov.bs/cms/images/LE GISLATION/PRINCIPAL/1873/18730015/PenalCode_1.pdf

Puerto Rican Federal Relations Act (JonesShafroth Act), Pub. L. No. 64-368, § 39, Stat. 951 (1917).

Puerto Rico Civil Code (Foraker Act), (Puerto Rico) Pub. L. No. 56-191, § 31, Stat. 77 (1900).

Quieting Titles Act (1959) Bahamas (Ch.

393). http://laws.bahamas.gov.bs /cms/images/LEGISLATION/PRINCIPAL /1959/1959-0028/

QuietingTitlesAct_1.pdf

Sea Bathing Rules, Bahamas. (1938). http://laws.bahamas.gov.bs/cms/images/L EGISLATION/SUBORDINATE/ 1938/1938-0251/SeaBathingRules_1.pdf

Vagrancy Act (1939) Bahamas (Ch. 89). http://laws.bahamas.gov.bs/cms/images/LEGISLA TION/PRINCIPAL/1939/1939-

0022/VagrancyAct_1.pdf 